\title{
Impact of Wages to Investment Realization and Manpower Absorption Before and After the Implementation of PP no. 78 Year 2015
}

\author{
Nanik Lestari \\ Politeknik Negeri Batam \\ Batam, Indonesia
}

\begin{abstract}
This study aims to analyze the differences of realization investment and labor absorption before and after the implementation of government regulation (PP) No.78 year 2015 about remuneration at national and multinational company in Indonesia and measuring the impact of minimum wage to realization investment and labor absorption in Indonesia. This study using normality test, Wilcoxon signed rank and partial least square test. Data analyzed of this study using quarterly data in four-year research period at two years before and after implementation regulation to 34 provinces in Indonesia. The result found the difference of realization investment of national and multinational company and labor absorption of multinational company before and after implementation of PP No.78 year 2015 has each sig. value at $\mathbf{. 0 0 0}$ while labor absorption for national company have no difference between before and after the implementation regulation with sig. value at .316 . There is no significant impact minimum wage to realization investment national, multinational company and labor absorption multinational company showed by each $t$ count at $.986, .139$ and 1.346 smaller than $t$ table 1.974 while there is a significant impact of minimum wage to labor absorption national company showed by $t$ count at 5.765 higher than $t$ table 1.974 .
\end{abstract}

Keywords - investment realization, wilcoxon, labor

\section{INTRODUCTION}

The new regulation of minimum wage in Indonesia which is Peraturan Pemerintah (PP) No.78 year 2015 has applicable after signed by President of Republic of Indonesia on 23 October 2015, this regulation indirectly revised the prior regulation PP no. 8 year 1981 about wages protection. Minister of Labor Republic of Indonesia response the implementation of PP no.78 year 2015 is a mandate for UU no.13 year 2013 about manpower to accommodate and ease entrepreneur on planning and maintain their wage policy, set a better proportion for wage structure, rights coverage for labor and set administrative sanctions for company that do not pay minimum wage as standard [1]. The usual phenomenon happen is the wages mismatch addressed by laborer to demand government and investor for their welfare. Issues happened, almost every year laborer held strike action demand the increase of minimum wage. Investor consider that their business plan will effected specially the operational cost for laborer wage that will increase every year due the implementation of this regulation, this issues has match Keynes theory "wage level will have caused the ups and downs on investment [2]. Unfortunately, the issuance of PP No.78 year 2015 still not chase the phenomenon the demand of minimum wage increment in Indonesia specially in Batam and Batamindo Industrial Park because laborer assume that this regulation the increment of minimum wage does not significantly contribute to their worth living components and just ease the investor.

Keynes theory said the increase of wage level will cause the increment of money supply in transaction and speculation motif thus causing the interest rate arises. The increment of wage level will increase the interest rate in assumption the stability of money supplied, Stonier and Haque [2]. The increment of interest can make the deposit rate and loan credit increase and cause the ups and downs investment in rill sector.

Competitive market theory by Mankiw said a market is a place which many buyers and sellers exist so each buyers or sellers has the small influence for the market price [3]. The actual condition that laborer sell a service to investor and minimum wage as a determination price and economy principle for the price offer from laborer must be agreed upon parties and this is mean the wage amount from laborer will negatively affect job demand.

The condition of labor minimum wage that higher than balance level causing the downs of laborer demand from investor and this means the work opportunity also down. The amount supplied (quantity supplied) for laborer that can supply to investor with a determination price for laborer, so the supply is positively related to the price [3].

The increment of company cost to hire laborer will cause the production cost arise or bit more expensive, this can reduce customer interest. The company will cut cost production such as laborer that triggered the production cost arises, the impacts will make labor demand downs. This condition can cause the structural unemployment and the jobs opportunity downs [3].

\section{LITERATURE}

The research conducted by Malau found that labor demand in industrial sector is very responsive to the level of investment [4]. Other studies by Anggrainy [2] and Hermawan [5] found labor demand to influenced by investment growth. 
The research of increase of minimum wage impact to the labor absorption conducted by Anggrainy [2] and Octivaningsih found the increment of minimum wage has a negative significant effect on labor absorption [6], another study conducted by Gorry found that increasing minimum wages may lead to increase unemployment youth rate in Europe [7].

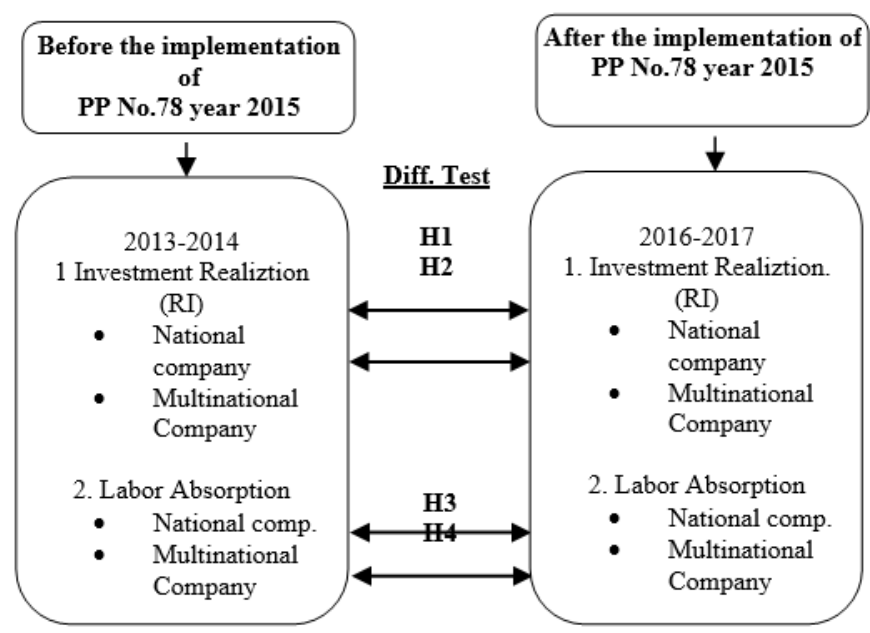

Fig. 1. Conceptual framework hypothesis for comparison difference before and after the regulation implementation.

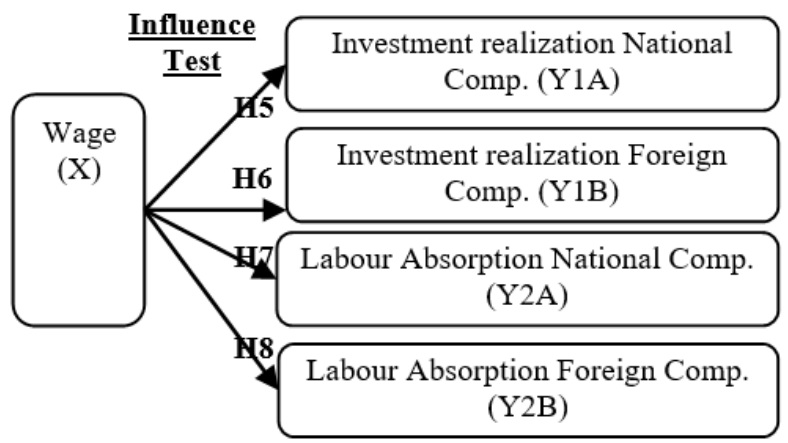

Fig. 2. Conceptual framework hypothesis for wage impact to investment realization and labor absorption.

\section{STUDY RESULTS}

\section{A. Descriptive Statistics}

TABLE I. TABLE TYPE STYLES

\begin{tabular}{|l|c|l|l|l|l|}
\hline & $\mathbf{N}$ & Minimum & Maximum & \multicolumn{1}{|c|}{ Mean } & Std. Dev. \\
\hline Province & 544 & 1 & 34 & 17.50 & 9.820 \\
\hline Wage & 544 & 830000 & 3355750 & 1704515.10 & 483154.006 \\
\hline IR_Nat. (Rp Mill) & 544 & .00 & 15561422.70 & $1.4023 \mathrm{E} 6$ & $2.57786 \mathrm{E6}$ \\
\hline $\begin{array}{l}\text { IR_MNC (US\$ } \\
\text { Thousand) }\end{array}$ & 544 & .00 & 2204960.90 & 217557.0426 & $3.51598 \mathrm{E} 5$ \\
\hline LA_Nat. & 544 & 0 & 71080 & 3659.67 & 6803.464 \\
\hline LA_MNC & 544 & 0 & 124114 & 7261.51 & 14657.212 \\
\hline
\end{tabular}

Based on the tested results, in the range of year 2013, 2014, 2016 and 2017 for all provinces in Indonesia found the average value of all variables are wages amount to $\mathrm{Rp} 1,704,515$, Realization investment for domestic company Rp 14.02 trillion, foreign company US \$ 2.17 billion, labor absorption of national companies of 3,659 workers and MNC of 7.261 workers. The lowest minimum wage found Rp 830,000 which is the minimum wage of Central Java province in 2013 and the highest minimum wage is $\mathrm{Rp} 3,355,750$ which is the minimum wage of DKI Jakarta province in 2017. The highest realization of investment of national company is Rp 15.56 trillion for East Java province in the second quarter of 2017 and the highest realization of foreign investment of US \$ 2.2 billion in West Java province in the third quarter of 2013. The absorption of the highest PMDN employment was 71,080 in East Java in the second quarter of 2013 and the absorption of the highest foreign company was 124,114 workforce in West Java province fourth quarter 2016 .

\section{B. Normality Test}

TABLE II. NORMALITY RESULT

\begin{tabular}{|lc|l|l|l|}
\hline \multicolumn{2}{|c|}{$\begin{array}{c}\text { Unstandardized } \\
\text { Residual Y1A }\end{array}$} & $\begin{array}{c}\text { Unstandardized } \\
\text { Residual Y1B }\end{array}$ & $\begin{array}{c}\text { Unstandardized } \\
\text { Residual Y2A }\end{array}$ & $\begin{array}{c}\text { Unstandardized } \\
\text { Residual Y2B }\end{array}$ \\
\hline $\begin{array}{l}\text { Klmgrv- } \\
\text { SmirnovZ }\end{array}$ & 6.728 & 5.442 & 5.033 & 6.556 \\
\hline $\begin{array}{l}\text { Asymp.sig. } \\
\text { (2tail) }\end{array}$ & .000 & .000 & .000 & .000 \\
\hline
\end{tabular}

Source: Data processed with EViews 10.0

Based on the table, value of Kolmogorov-Smirnov on investment realization national company or Y1A company is 6,728 significant at 0.000 and on residual value of investment realization of multinational company or $\mathrm{Y} 1 \mathrm{~B}$ is 5,442 significant at 0.000 . The residual value for labor absorption of national company or Y2A is 5,033 significant at 0.000 and on residual labor absorption value of multinational company or $\mathrm{Y} 2 \mathrm{~B}$ is 6,556 significant at 0.000 . The significant value of these four variables is smaller than .050. This shows that data residuals has not normal distributed and can only be tested with non-parametric on the test hypothesis.

\section{The Result of Hypothesis}

TABLE III. HYPOTHESIS THESIS RESULT

\begin{tabular}{|c|l|l|l|l|}
\hline Hypothesis & \multicolumn{1}{|c|}{ Test } & \multicolumn{1}{|c|}{ Value } & \multicolumn{1}{|c|}{ Parameter } & \multicolumn{1}{|c|}{ Decision } \\
\hline $\boldsymbol{H 1}$ & Wilcoxon & .000 & Sig. $<0.05$ & Supported \\
\hline $\boldsymbol{H 2}$ & Wilcoxon & .040 & Sig. $<0.05$ & Supported \\
\hline $\boldsymbol{H 3}$ & Wilcoxon & .316 & Sig. $<0.05$ & Not Supported \\
\hline $\boldsymbol{H 4}$ & Wilcoxon & .000 & Sig. $<0.05$ & Supported \\
\hline $\boldsymbol{H 5}$ & $\begin{array}{l}\text { Partial Least } \\
\text { Square }\end{array}$ & .889 & tcount $>.1 .964$ & Not Supported \\
\hline $\boldsymbol{H 6}$ & $\begin{array}{l}\text { Partial Least } \\
\text { Square }\end{array}$ & .334 & tcount $>.1 .964$ & Not Supported \\
\hline $\boldsymbol{H 7}$ & $\begin{array}{l}\text { Partial Least } \\
\text { Square }\end{array}$ & 5.765 & tcount $>.1 .964$ & Supported \\
\hline $\boldsymbol{H 8}$ & $\begin{array}{l}\text { Partial Least } \\
\text { Square }\end{array}$ & 1.346 & tcount $>.1 .964$ & Not Supported \\
\hline
\end{tabular}

1) Hypothesis 1 and 2: The significance value of the investment realization for national company or Y1A is lesser than .050, and the significance value for multinational 
companies or Y1B is significant at .040 which smaller than .050 , these means there are differences between before and after the implementation of PP No.78 year 2015 to the national and multinational company in investment realization, this indicates Hypothesis 1 \& Hypothesis 2 supported on the research.

Based on the above result, the investment realization for national and multinational companies in Indonesia are sensitive to the implementation of PP No.78 year 2015 as the new policy for wages it can also possibly caused by another factors that directly affect the investment policies such as economic growth, Gross Regional Domestic Product (GDRP), inflation, politics, rising world oil prices and other macroeconomic factors which is not explained in the study. During the period study the trend of investment realization can be seen from the Figure 3 and 4 below.

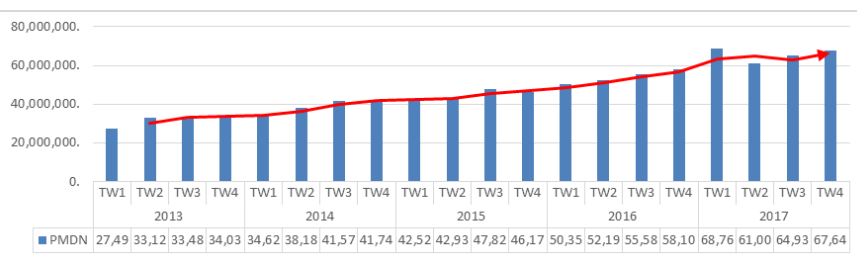

Source: BKPM official publication per quarter IV 2017

Fig. 3. Graph realization of investment national companies in Indonesia 2012-2017.

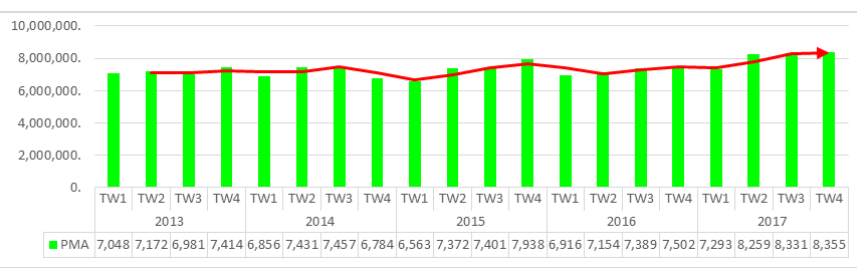

Source: BKPM official publication per quarter IV 2017

Fig. 4. Graph realization of investment multinational companies in Indonesia 2012-2017.

The increase of investment realization in the period after the implementation of PP No.78 year 2015 (year 2016 to 2017) shown a consistent increase and positive upcoming trendline compare to the period before the implementation (year 2012 to 2014) which is not too high.

2) Hypothesis 3 and 4: The significance value for labor absorption national company or Y2A at .316 bigger than .050 , and the significance value for multinational companies or $\mathrm{Y} 2 \mathrm{~B}$ is significant at .000 which smaller than .050 , these means there is no differences between before and after the implementation of PP No.78 year 2015 to the labor absorption for national companies but there is a difference for multinational company labor absorption that indicates Hypothesis 3 is not supported while Hypothesis 4 supported on the research.

Differences at the test results for labor absorption national and multinational companies during study period as shown by data because national companies have a limited business capital compare to the multinational companies which have foreign capital support and more diverse and be bigger capital structure than national companies. The trend of labor absorption in study period showing fluctuations, which can be seen on the figure 5 below:

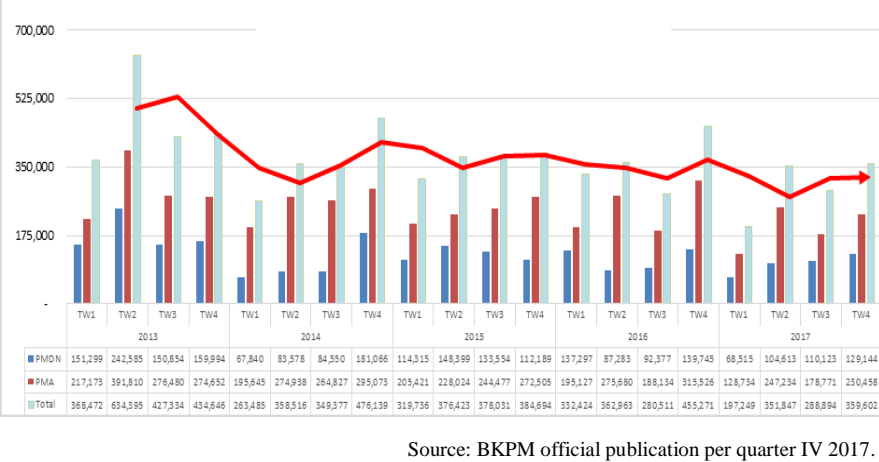

Fig. 5. Employment graph for national and multinational companies in Indonesia 2012-2017.

From the figure 5, development of labor absorption in Indonesia shows a sideways trend with no certain pattern of the fluctuation which formed on the labor absorption development every year. This also proved the result analysed why H3 and $\mathrm{H} 4$ has a different result.

3) Hypothesis 5 and 6: $t_{\text {count }}$ value of wage to investment realization for national companies or Y1A shows at .889 lesser than $t_{\text {table }}$ at 1.964 , for $t_{\text {count }}$ value variable wage to investment realization multinational national companies or Y1B shows at .334 that also lesser than $t_{\text {table }}$ at 1.964 , these means there is no significant impact wage to the investment realization for national and multinational company in study period. This indicates Hypothesis 5 and Hypothesis 6 is not supported on the research.

It is possible that the realization of investment in Indonesia during study period is not affected by wage because investment need a longer time, well organized and good plan to be executed as capital expenditure in developing its business because it has been well planned in the previous period. Other things that possibly happen because the realization of investment in Indonesia are more responsive by other variable that directly impact such as changes in investment policy, economic conditions, politics, crisis and other macroeconomic factors.

4) Hypothesis 7 and 8: $\mathrm{t}_{\text {count }}$ value of wage to labor absorption for national companies or Y2A shows at 5.765 bigger than $\mathrm{t}_{\text {table }}$ at 1.964 , for $\mathrm{t}_{\text {count }}$ value variable wage to labor absorption for multinational national companies or Y2B shows at 1.346 lesser than $t_{\text {table }}$ at 1.964 , these means there is a significant impact wage to the labor absorption for national while there is significant impact wage to the multinational company in study period. This indicates Hypothesis 7 supported while Hypothesis 8 is not supported on the research.

Labor absorption is different than realization of investment because the realization of investment is the company's capital expenditure in conducting business development and labor absorption is how many companies can increase economic 
value by hiring people as labor for their business. Another thing considered of the different result between national and multinational companies are the business ownership that national company may have no various ownership than multinational company, number of the share for each parties and assumption that national company more concern to the government regulation rather than multinational company.

\section{IMPLICATIONS}

The Implementation of PP no. 78 year 2015 in Indonesia as the new regulation to maintain a better wage structure has met pro and contra since its commencement date. Both parties between investor and laborer has their own perspective to look and responding this regulation especially every year of mayday in Jakarta and some of central region with high number of workforces in Indonesia. From the economic side as seen by result of this study found a better outcome in number of investment realization after this regulation implemented indicate Indonesia's government moving to the right step for economic development to help investor and laborer with a better scheme of wage structure. This study containing implication for the opposite statement that confront the implementation of PP No. 78 year 2015 which said it will lead Indonesia to bad economic system to not think sceptic due this regulation cannot cover all parties interest.

As predicted by some of international organisation including IMF which indicate Indonesia potentially become a new global economic power by 2030 if meet some assumption which are consistent of National Economic Growth, Infrastructure Development and friendly economic policy for investor, this study will help to measure how wage can contribute to Indonesia's development. To what extent of future study with the same topic suggested to widen the component, variable and increase length of research.

\section{CONCLUSION}

The result found the difference of realization investment of national and multinational company and labor absorption of multinational company before and after implementation of PP No.78 year 2015 has each sig. value at .000 while labor absorption for national company have no difference between before and after the implementation regulation with sig. value at .316. There is no significant impact minimum wage to realization investment national, multinational company and labor absorption multinational company showed by each $t$ count at $.986, .139$ and 1.346 smaller than $\mathrm{t}$ table 1.974 while there is a significant impact of minimum wage to labor absorption national company showed by $t_{\text {count }}$ at 5.765 higher than $t$ table 1.974 .

\section{REFERENCES}

[1] Tempo, Tempo.co. Retrieved from Tempo Media Group, 2017 [Online]. Retrieved from: https://nasional.tempo.co/read/1030141/pp-nomor-78tahun-2015-mengakomodir-upah-karyawan

[2] K. Anggrainy, “Analisis Dampak Kenaikan Upah Minimum Kota (UMK) terhadap Kesempatan Kerja dan Investasi (Studi Kasus pada Kota Malang Periode 2001-2011)," Jurnal ilmiah. Jurusan Ilmu Ekonomi, Fakultas Ekonomi dan Bisnis,Universitas Brawijaya, Malang, 2013.

[3] G. Mankiw, Makroekonomi. Jakarta: Erlangga, 2006.

[4] A.G. Malau, "Dampak Tenaga Kerja Sektor Industri Terhadap Produk Domestik Regional Bruto, Pajak, Investasi, dan Upah Di Kota Batam,'” Jurnal Organisasi dan Manajemen, vol. 8, no. 1, pp. 13-21, 2012.

[5] I. Hermawan, "Analisis Dampak Kebijakan Makroekonomi Terhadap Perkembangan Industri Tekstil Dan Produk Tekstil Indonesia,” Jurnal Buletin Ekonomi Moneter dan Perbankan, 2011.

[6] A.R. Octivaningsih, Analisis Pengaruh Nilai Upah Minimum Kabupaten terhadap Investasi, Penyerapan Tenaga Kerja, dan PDRB di Kabupaten Bogor (Skripsi). Bogor: Fakultas Ekonomi dan Manajemen Institut Pertanian Bogor, 2006.

[7] A. Gorry, "Minimum wages and youth unemployment," European EconomicReview, pp. 57-75, 2013. 